\title{
Miners and mining in the Late Bronze Age: a multidisciplinary study from Austria
}

Jörg Schibler ${ }^{1}$, Elisabeth Breitenlechner ${ }^{2}$, Sabine Deschler-Erb ${ }^{1}$, Gert Goldenberg ${ }^{3}$, Klaus Hanke ${ }^{4}$, Gerald Hiebel ${ }^{4}$, Heidemarie Hüster Plogmann ${ }^{1}$, Kurt Nicolussi ${ }^{5}$, Elisabeth Marti-Grädel ${ }^{1}$, Sandra Pichler ${ }^{1}$, Alexandra Schmidl ${ }^{2}$, Stefan Schwarz ${ }^{2}$, Barbara Stopp ${ }^{1} \&$ Klaus Oeggl $^{2}$

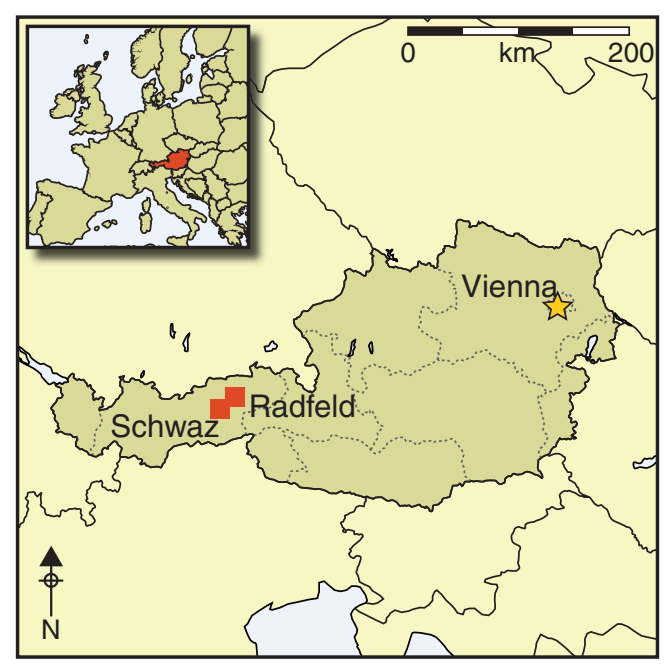
scarcely hunted or foraged the resources of the local forest. They seem to be the servants of a command economy, encouraged to keep their minds on the job.

Keywords: Austria, Late Bronze Age, mining, environment, economy

1 Institute for Prehistory and Archaeological Science (IPAS), Basel University, Spalenring 145, CH-4055 Basel, Switzerland

2 Institut für Botanik, Leopold-Franzens-Universität Innsbruck, Sternwartestrasse 15, A-6020 Innsbruck, Austria

3 Institut für Archäologien, Leopold-Franzens-Universität Innsbruck, Langer Weg 11, A-6020 Innsbruck, Austria

4 Vermessung und Geoinformation, Leopold-Franzens-Universität Innsbruck, Technikerstrasse 13, A-6020 Innsbruck, Austria

5 Institute of Geography, University of Innsbruck, Innrain 52, A-6020 Innsbruck, Austria

Received: 3 August 2010; Accepted: 21 September 2010; Revised: 3 March 2011

ANTIQUITY 85 (2011): 1259-1278

http://antiquity.ac.uk/ant/085/ant0851259.htm

The extraction and processing of metal ores, particularly those of copper and tin, are regarded as among the principal motors of Bronze Age society. The skills and risks of mining lie behind the weapons, tools and symbols that drove political and ideological change. But we hear much less about the miners themselves and their position in society. Who were these people? Were they rich and special, or expendable members of a hardpressed workforce? In this study the spotlight to the bones and seeds, providing a sketch of dedicated prehistoric labourers in their habitat. The Mauken miners were largely dependent on imported meat and cereals, and 1259 


\section{Introduction}

The mining industry underpinned the innovations of the Bronze Age, and yet we still know little about the environment and economy of the mining communities. Current research questions concern the raw materials exploited, the structure of the mining landscapes, the technologies applied, the mining culture and the effects of mining activities on environments and human societies alike. In particular, we need to explore aspects of the mining populations' food supply and diet. Among the key regions for the study of prehistoric mining is the Mauken mining district (Tyrol), which was active from the Late Bronze to Early Iron Age. Here we present new information about these miners, who have been the subject of an interdisciplinary project investigating their local environment and food supply as well as the methods by which metal was extracted and processed.

\section{The Mauken mining district}

The Mauken mining area is located in the Radfeld/Brixlegg region of the Lower Inn Valley. The area between Schwaz in the west and Radfeld in the east, extending along the southern side of the central Lower Inn Valley, is well known for mining in the early modern period. Cupriferous and argentiferous Fablore was extracted on a large scale and the area became one of Europe's leading mining centres in the fifteenth and sixteenth centuries AD, as celebrated in the sixteenth-century 'Schwazer Bergbuch' (Bartels et al. 2006).

Archaeological field research undertaken since the 1990s has revealed that the area had also been the location of a mining boom from the Late Bronze to the Early Iron Age, also targeting the copper-bearing Fablore deposits (Rieser \& Schrattenthaler 2000; Goldenberg $\&$ Rieser 2004). The Mauken Valley near Rattenburg (Figure 1, inset), situated at an altitude between 900 and 1200m asl, is of special interest (Goldenberg \& Rieser 2004; Goldenberg 2008; Klaunzer et al. 2010). Mining here exploited the eastern branch of Fablore deposits in the so-called 'Schwaz dolomite' (Pirkl 1961).

\section{Investigations}

The recent campaign of excavations in the Mauken Valley (2000-2009) involved five main sites and took place within a broader Austrian research project (HiMAT) aimed at a fuller understanding of the prehistory of mining. Using data from archaeological excavations in the 1990s (Goldenberg \& Rieser 2004) and magnetic field measurements conducted in 2007 (Terrana Geophysik, Mössingen), the well-preserved in situ remains of a smelting site were excavated in 2008 at Mauk A (Figure 1). Two furnaces and a dual-phase ore roasting bed were defined, and an excavation trench was cut through a heap of slag-sand in order to recover organic remains for archaeozoological and archaeobotanical analyses. The animal bones (food waste), mostly stained green by copper salts, were preserved exceptionally well. The archaeobotanical macroremains, on the other hand, were in a poorer state of preservation (Schatz et al. 2002; Heiss \& Oeggl 2005, 2008).

Mine shafts were investigated at Mauk B and Mauk E (2009), the latter extending some $25 \mathrm{~m}$ into the mountain (Figure 2). Mauk D, investigated in 2000, was the site of a small group of mine shafts located on a terrace, where exploratory excavations uncovered the 


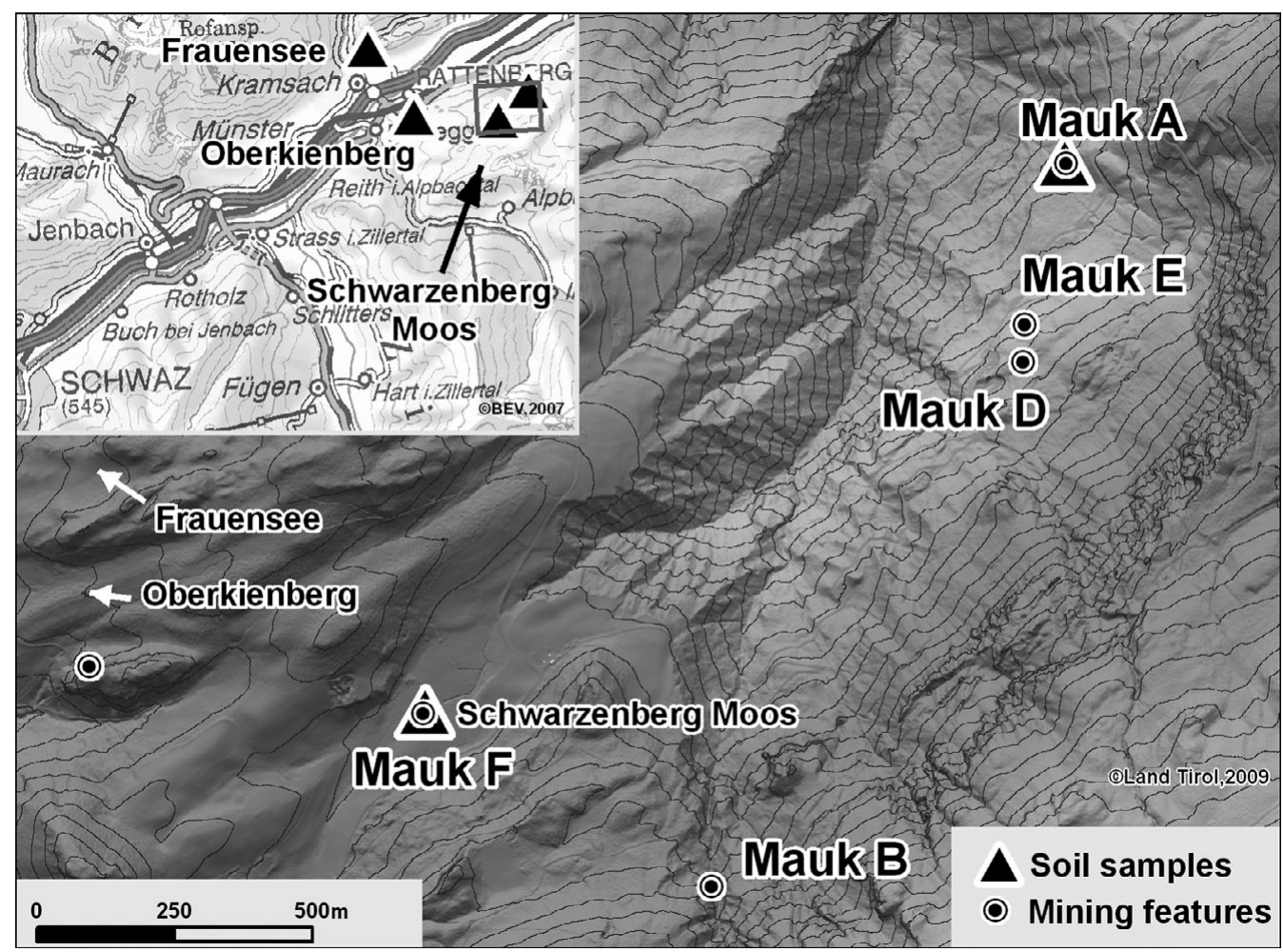

Figure 1. Location of the principal sites discussed, with (inset) location of the pollen sampling points.

remains of a work camp for ore processing adjacent to the mine adits. A feature of the site was a 'midden' containing a rich assemblage of ceramics, animal bones and stone tools. In 2007/08 a small, well-preserved ore processing site (Mauk F) was recorded and explored extensively by archaeological excavations in the Schwarzenberg-Moos, a former bog, now practically drained. Upon discovery, the features were completely embedded in peat deposits. Remains of tree stumps and chop notches at the bottom of the site indicate that a work camp had been created in the boggy area by clearing a formerly wooded plot.

The vegetation history of the region was documented by pollen profiles taken at three points along a transect from the valley floor up to a middle upland elevation (located as black triangles in Figure 1, inset). The sample at the highest altitude was taken at the Schwarzenberg-Moos (Mauk F) site at $1140 \mathrm{~m}$ asl. This was compared with palynological data from a blanket bog on a slope at $757 \mathrm{~m}$ asl and the Frauensee profile from the valley floor at $560 \mathrm{~m}$ asl (Walde 1999). All sites were located in the fir and beech forest (Abieti-Fagetum) with beech (Fagus) proportions declining with altitude. The present climate is oceanic in character, with heavy snowfall during the cold season.

Materials were thus obtained which throw light on extraction (at Mauk B and E), the crushing and washing of the ore (Mauk F), the roasting and smelting of the ore to produce metal (Mauk A), the ambient vegetation (from three pollen cores), and the economy (plants from Mauk A and animal bones from Mauk A and D). Typological 


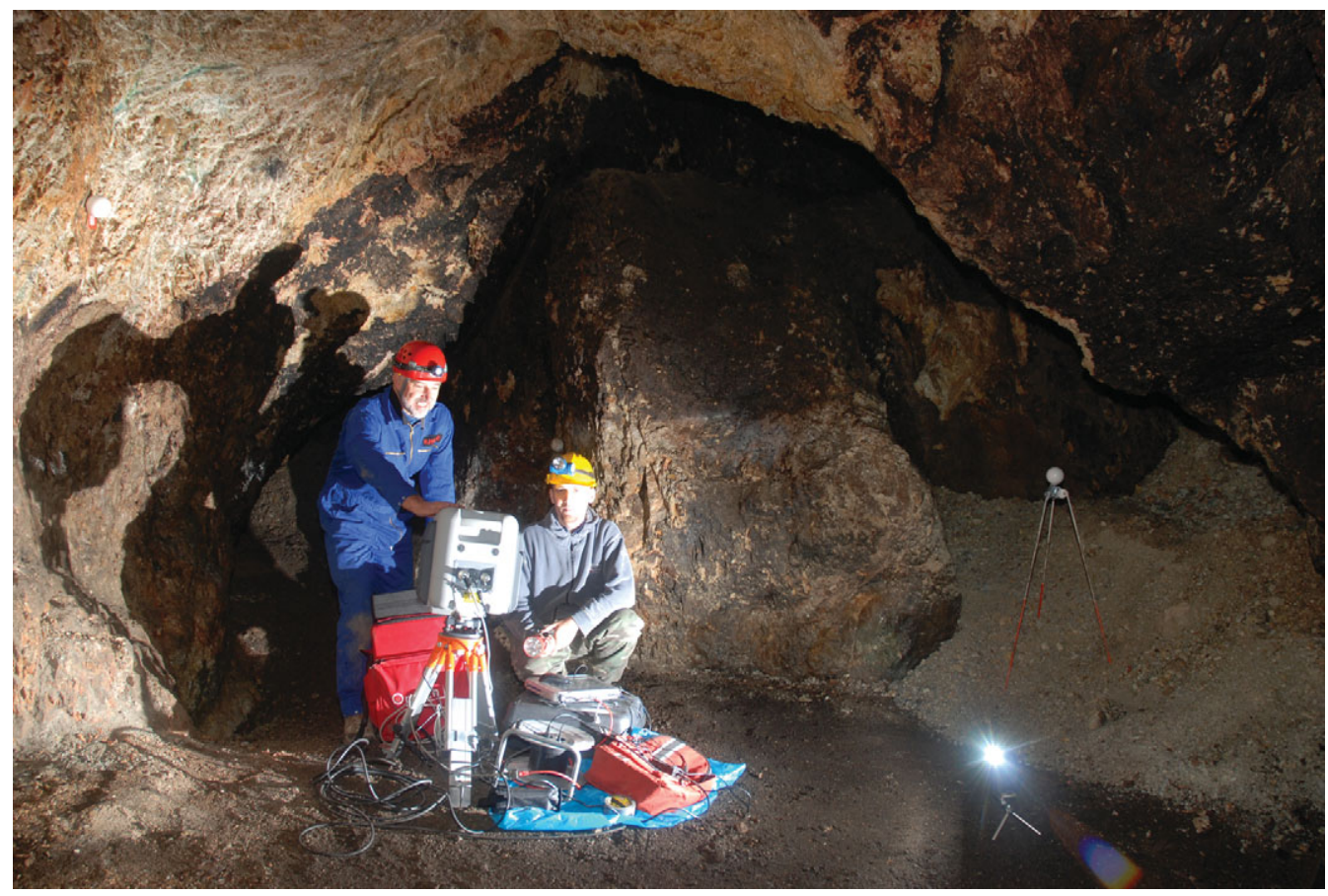

Figure 2. Recording the prehistoric Fahlore mine at Mauk E with laser-scanning techniques.

characteristics of the ceramics and radiocarbon dates indicate that the Mauk A and D sites date to the twelfth/eleventh centuries BC, that is to the Late Bronze Age. Radiocarbon and dendrochronology chronicle the mining activity into the ninth century (Mauk F) and the eighth-fifth centuries (Mauk E).

\section{Methods of extraction and processing}

Fire-setting, which produces dome-shaped cavities in the hard dolomite rock, was the characteristic technique employed in prehistoric extraction in the Mauken Valley (Figure 3). Charred wood from fire-setting at Mauk E gave a dendrochronological date in the late eighth century $\mathrm{BC}$, as well as providing information on the local forest formation and its exploitation. There were also traces of the sixteenth-century $\mathrm{AD}$ ore extraction on the inside of the mine. At Mauk F, Late Bronze Age miners crushed the ore and used the water running from the bog into the Mauken Valley to concentrate the mined material, using wooden troughs as settling tanks (Figure 4). Smelting operations were defined at Mauk A on a natural plateau below 'Sommerauer Wände' through which a small creek flows; here ore was roasted and smelted in furnaces (Figure 5). The slag heap at Mauk A proved very informative. Approximately 100 tonnes of copper slag that had been crushed to the consistency of sand attest to the systematic treatment of the slag produced in the furnaces in order to separate any remaining copper and optimise metal yields (Figure 6). Gravity-separation was accomplished by washing the crushed slag through channels. One such wood-planked channel was recorded during excavations in 1997 (Goldenberg 2008). 


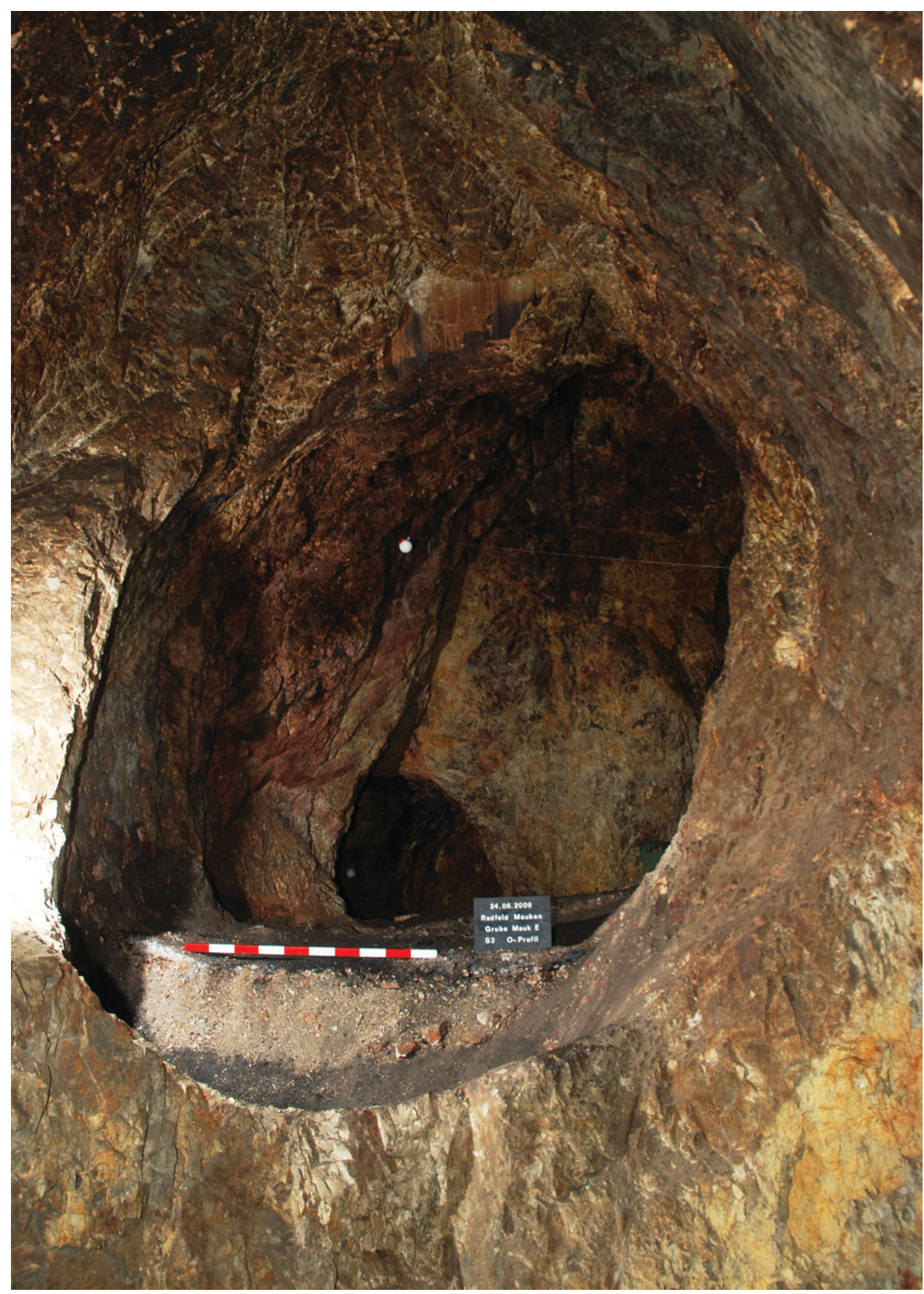

Figure 3. A typical round hollow resulting from extraction of ore by fire-setting (at Mauk E, eighth century BC). 


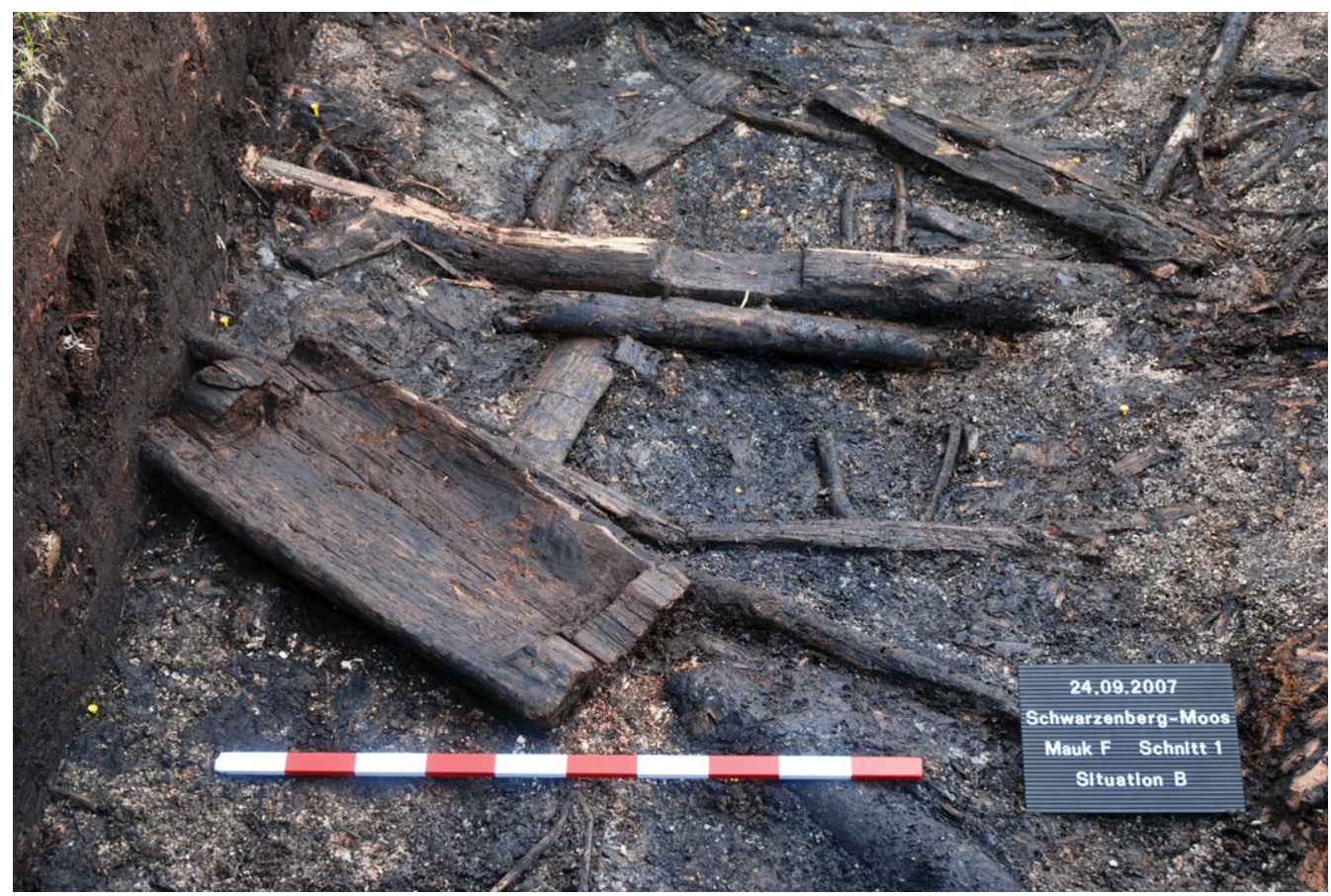

Figure 4. Wooden trough in the ore washing plant at Mauk F (ninth century BC).

Due to its high residual content in copper salts, organic materials are well preserved in the slag-sand. Given the relatively small concentration of mining works in this area, it can be assumed that one central smelting site was sufficient for local metal production. The copper output took the form of ring ingots.

\section{Environment}

The results of the three Schwarzenberg-Moos pollen profiles are shown in Figure 7 and Table 1. In the upland zone (Figure 7A), the end of the Neolithic was characterised by spruce forests (Picetum) with a low admixture of fir (Abies) and beech (Fagus). The immigration and expansion of both species in the investigation area 5000 years ago indicate a climatic change to wetter and cooler conditions (Tinner \& Lotter 2006). This suggests that these two species displaced larch (Larix) to higher altitudes and onto poorer soils (e.g. rock falls), where larch (Larix) and pine (Pinus) have an advantage (e.g. Mayer 1964). During the first half of the Early Bronze Age, a decline in spruce (Picea) and an increase in grasses (Poaceae) signal the occurrence of pasture and the opening of the forest canopy. The simultaneous increase in charcoals (Particulae carbonae $>100 \mu \mathrm{m}$ ) indicates intensified fire activity and documents the first human impact in the research area. The ensuing forest regeneration is characterised by a spread of birch, followed by pine and spruce. Subsequently, there grows a mixed mountain forest with fir, spruce and a low admixture of beech. In the Middle Bronze Age spruce decreases while pine and larch increase. Indications of pasture become more numerous, with signs of isolated settlement. In the Late Bronze Age a marked clearing 


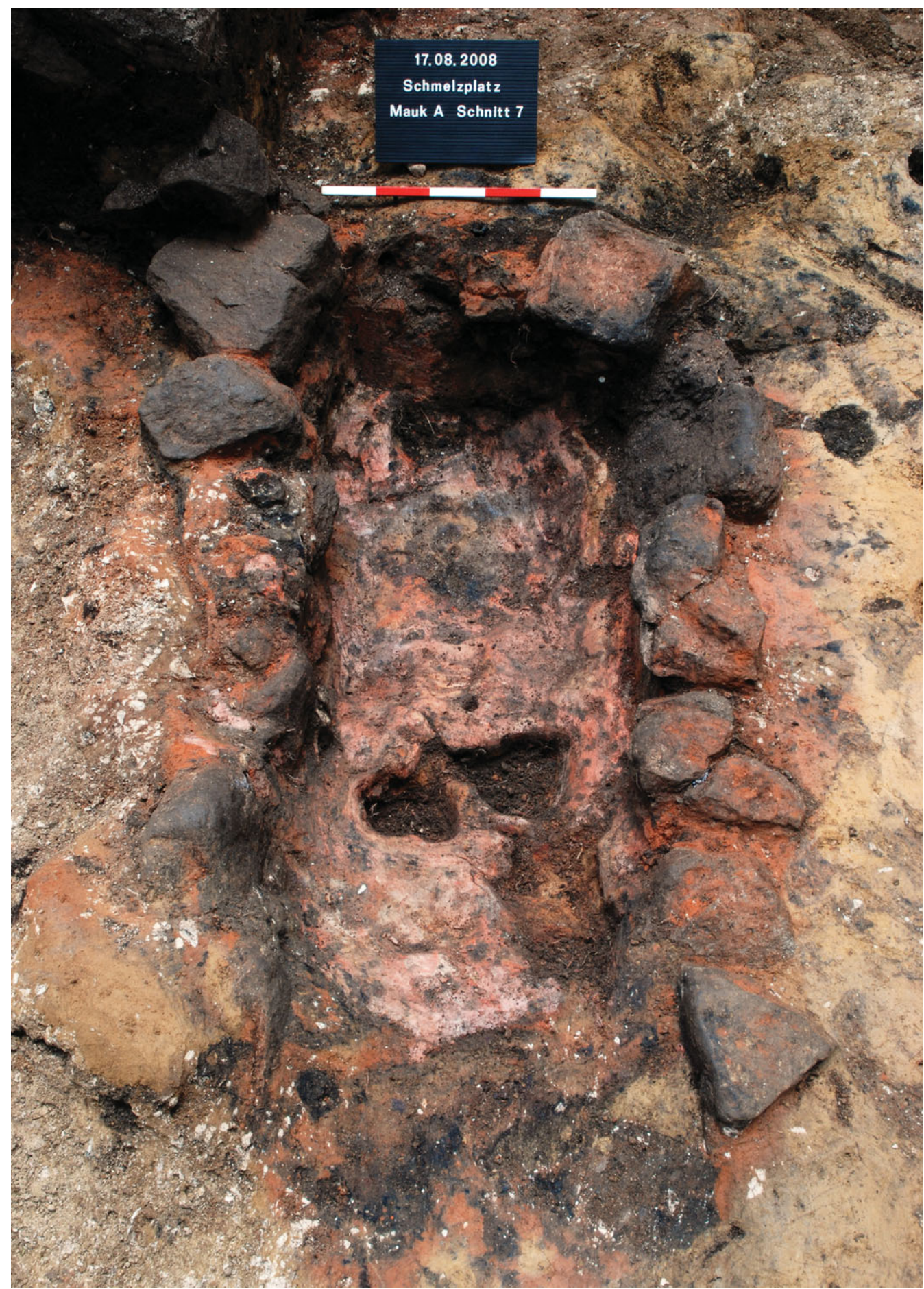

ปี

Figure 5. Base of a Fahlore smelting furnace at Mauk A (twelfthleleventh century BC). 


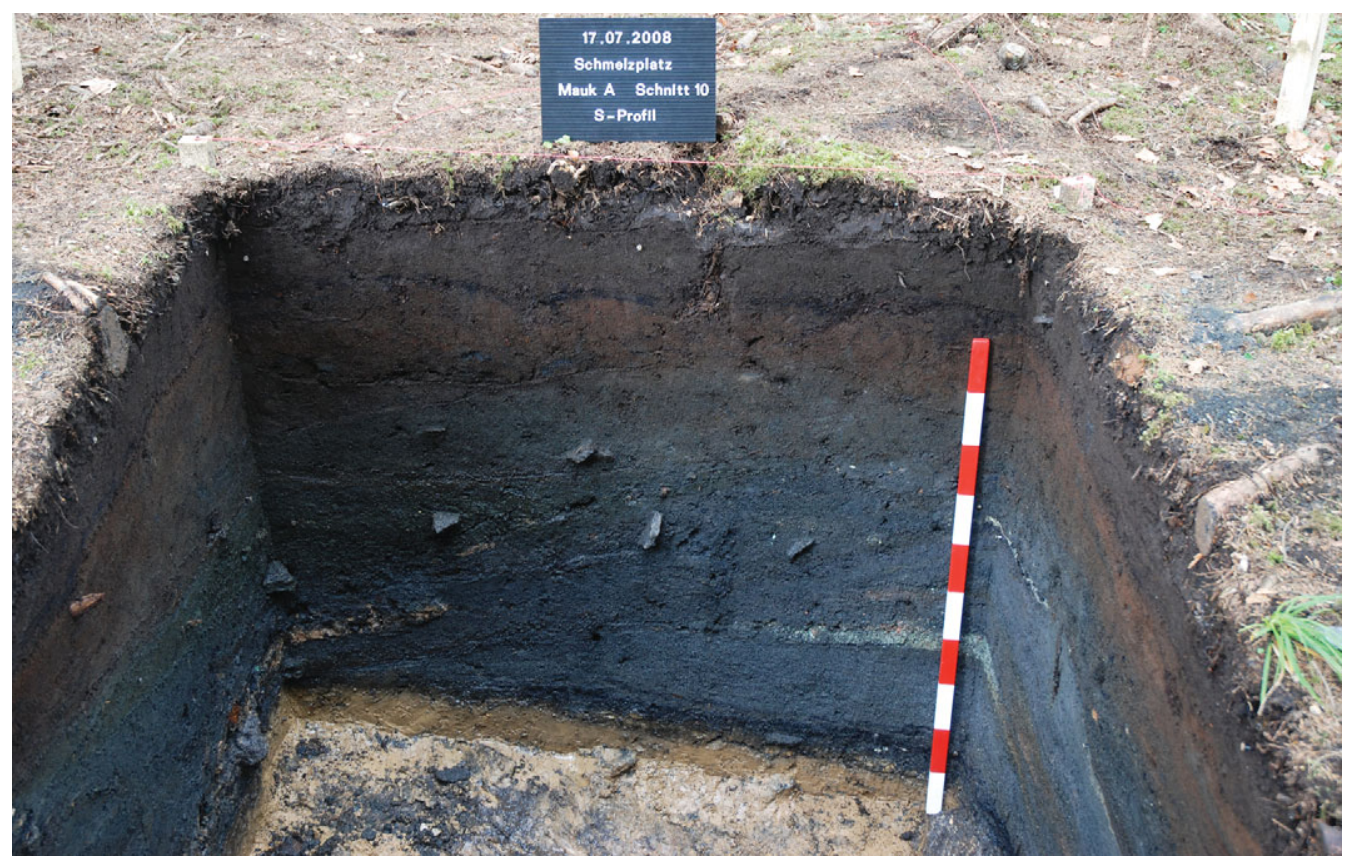

Figure 6. Deposit of slag-sand, smelting site Mauk A (twelfthleleventh century BC).

stands out. While spruce, larch and pine decline, the occurrence of pasture and settlement indicators, as well as high quantities of charcoal, mark a local anthropogenic impact. A layer of sand is probably owed to disturbance from the establishment of the Schwarzenberg-Moos ore processing site (Mauk F). The increase of pasture indicators and grasses suggest that while ore processing took place, animals were grazing in the vicinity. At the end of the Bronze Age, human impact decreases and a fir/spruce forest (Piceto-Abietetum) emerges.

Further down the slope, the botanical development is documented in the profile from the Oberkienberg bog (Walde 1999; Figure 7B) situated about 3km west of SchwarzenbergMoos. At the end of the Neolithic, a spruce forest with a low admixture of beech and fir dominates. At the transition to the Early Bronze Age, pasture and settlement indicators as well as higher values of local charcoals suggest a moderate human impact, probably providing pastoral activities. At these lower altitudes and in favourable habitats there are still mixed forests with oak (Quercus), lime (Tilia), elm (Ulmus), ash (Fraxinus) and maple (Acer). Human impact is documented by charcoal maxima, a decrease of spruce and an increase of settlement indicators during several episodes from $2000 \mathrm{BC}$ to the end of the Bronze Age. The small-scale, local thinning of the spruce forest (Piceetum) favours hazel (Corylus avellana) and birch (Betula). Increases in grasses and pasture indicators suggest forest pasturing. Human impact decreases at the transition to the Iron Age and values of beech and fir increase until the recurrence of settlement indicators around $500 \mathrm{BC}$.

The Frauensee pollen diagram (Walde 1999) gives information on the vegetation history on the valley floor (Figure 7C). Beeches dominate the spruce/beech forest (Abieti-Fagetum) in the catchment area of the lake, with some larch growing on rocky slopes. The constant 
Jörg Schibler et al.
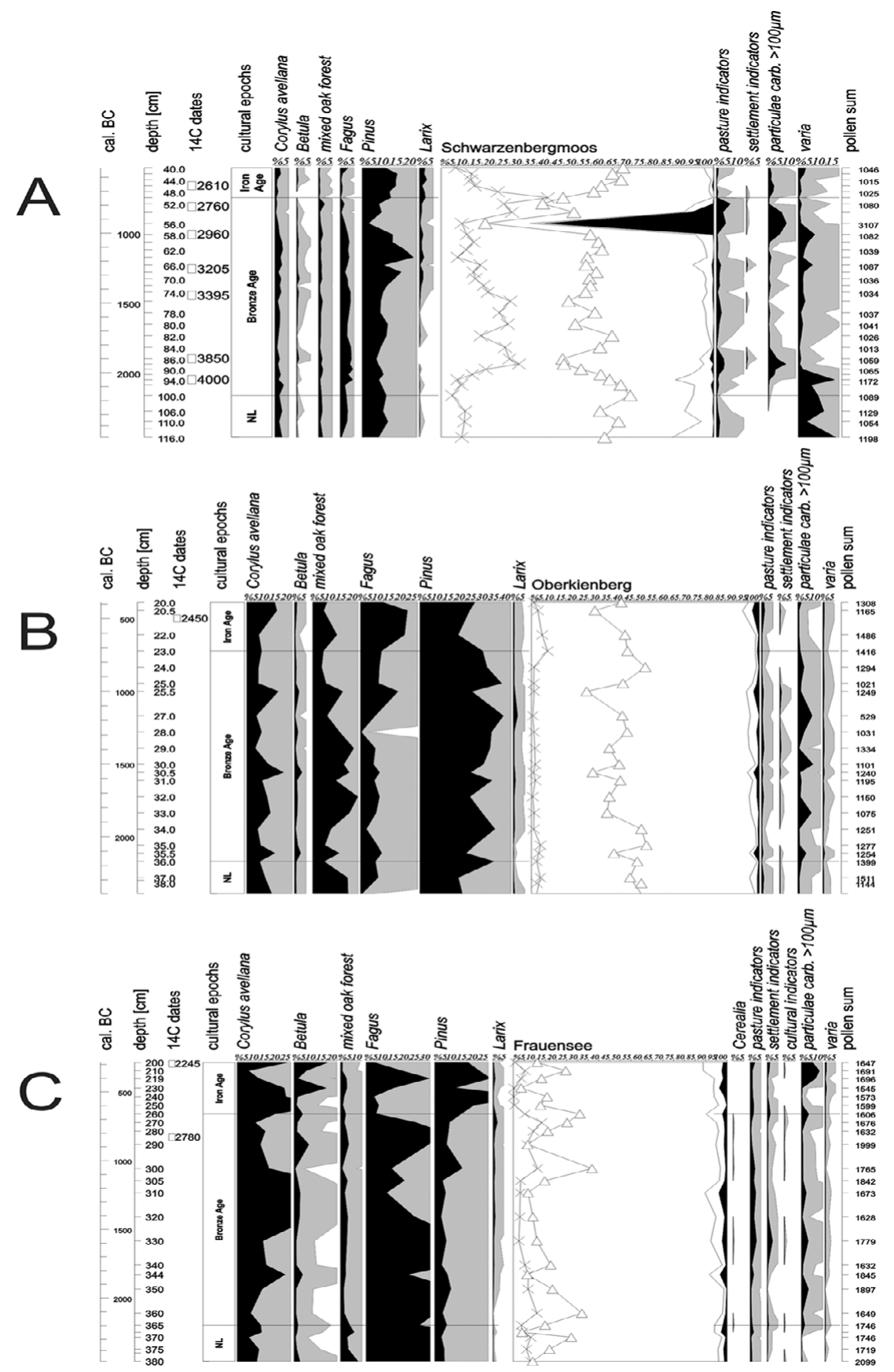

Figure 7. Pollen profiles from three sites in the Mauken area: A) upland (Schwarzenberg-Moos $1140 \mathrm{~m}$ asl); B) hillside (Oberkienberg $757 \mathrm{~m}$ asl); $C$ ) valley floor (Frauensee $560 \mathrm{~m}$ asl). The pollen diagrams Oberkienberg and Frauensee (according to Walde 1999) display only the relevant sections of longer pollen sequences with several radiocarbon dates. 
Table 1. Plant species indicating pasture, settlement and cultural indicators in the three pollen profiles. $(\mathrm{T} .=$ type $)$.

\begin{tabular}{|c|c|c|c|}
\hline & Pasture indicators & Settlement indicators & $\begin{array}{l}\text { Cultural } \\
\text { indicators }\end{array}$ \\
\hline Schwarzenberg-Moos & $\begin{array}{l}\text { Apiaceae, Brassicaceae, } \\
\text { Caryophyllaceae, Dipsacaceae, } \\
\text { Gentianaceae, Juniperus, } \\
\text { Pteridium aquillinum, } \\
\text { Ranunculus acris T., Rosaceae, } \\
\text { Rumex acetosa T., Scabiosa }\end{array}$ & $\begin{array}{l}\text { Artemisia, Plantago lanceolata } \\
\text { T., Rumex T. }\end{array}$ & \\
\hline Oberkienberg & $\begin{array}{l}\text { Achillea T., Apiaceae, } \\
\text { Brassicaceae, Caryophyllaceae, } \\
\text { Centaurea nigra T., Juniperus, } \\
\text { Papilionaceae, Plantago media, } \\
\text { Pteridium aquillinum }\end{array}$ & $\begin{array}{l}\text { Artemisia, Chenopodiaceae T., } \\
\text { Plantago lanceolata T., } \\
\text { Plantago media, } \\
\text { Rumex T., Urtica }\end{array}$ & \\
\hline Frauensee & $\begin{array}{l}\text { Achillea T., Apiaceae, } \\
\text { Brassicaceae, Caryophyllaceae, } \\
\text { Centaurea, Centaurea nigra T., } \\
\text { Juniperus, Papillionaceae, } \\
\text { Pteridium aquillinum, } \\
\text { Ranunculus acris T., Rumex T., } \\
\text { Thalictrum }\end{array}$ & $\begin{array}{l}\text { Artemisia, } \\
\text { Chenopodiaceae } \mathrm{T} . \text {, } \\
\text { Plantago lanceolata } \mathrm{T} ., \\
\text { Plantago major } \mathrm{T} ., \\
\text { Plantago media, Rumex } \mathrm{T} . \text {, } \\
\text { Urtica }\end{array}$ & Cerealia \\
\hline
\end{tabular}

presence of pasture, settlement and cultural indicators suggests a continuous settlement of the valley floor from the end of the Neolithic to the beginning of the Iron Age. Intensification of settlement activities characterised by the presence of cereal pollen (Cerealia) is documented in the close vicinity of Lake Frauensee during the Early, Middle and Late Bronze Age. These activities result in a thinning of the forests in which beech is cleared. The clearings are colonised primarily by hazel and birch. Settlement activities further increase during the Iron Age, leading to a proliferation of pine. In summary, the pollen analyses along the altitudinal transect document agro-pastoral settlements on the valley floor and a thinning of forests at higher altitudes by mining and/or pastoral activities.

\section{Economy}

Five waterlogged soil samples from three different areas at Mauk A were selected for detailed archaeobotanical analyses (Table 2). The samples were processed following the standard techniques of Jacomet and Kreuz (1999). Plant macrofossils were analysed using a stereo microscope and identified using standard literature (e.g. Berggren 1981; Cappers et al. 2006) and the seed and fruit reference collection at the Botanical Institute of Innsbruck University. Furthermore, anthracological analyses were conducted on randomly collected charcoal fragments $(>2 \mathrm{~mm})$ using a reflected-light microscope and wood identification literature (e.g. Schweingruber 1990; Schoch et al. 2004).

All five soil samples contained heavily decayed waterlogged organic material (roots/rootlets, bark and wood fragments), together with charcoal, but there was also a 
Table 2. Complete list of plant taxa recorded from five soil samples at Mauk A. Abundances of other components, bone fragments, insect remains and inorganics have been recorded semi-quantitatively on a three-point scale: ' $x$ ' $=$ present or moderately frequent, about $1-10 \%$ by volume; ' $x x$ ' $=$ common, about $10-50 \%$ by volume; ' $x x x$ ' $=$ abundant, $>50 \%$ by volume. Type of preservation indrawn as ' $w$ ' $=$ waterlogged, 'c' = carbonised.

\begin{tabular}{|c|c|c|c|c|c|c|c|c|c|}
\hline \multicolumn{4}{|l|}{ MAUKEN A: Mining area } & \multicolumn{2}{|c|}{ Cut 6} & \multirow{3}{*}{$\begin{array}{c}\frac{\text { Cut } 7}{\text { Smelting location }} \\
103\end{array}$} & \multirow{2}{*}{\multicolumn{3}{|c|}{$\begin{array}{c}\text { Cut } 10 \\
\text { Slag heap }\end{array}$}} \\
\hline \multicolumn{4}{|c|}{ MACROBOTANICAL ANALYSES } & \multicolumn{2}{|c|}{ Slag processing site } & & & & \\
\hline Sample no. & & & & 13 & 17 & & B6 & D4 & \\
\hline Total sample weight $(\mathrm{kg})$ & & & & 5.99 & 4.87 & 1.12 & 1.96 & 2.46 & \\
\hline Total charcoal weight $>2 \mathrm{~mm}(\mathrm{~g})$ & & & & 4.61 & 2.61 & 4.58 & 13.16 & 5.13 & \\
\hline \multicolumn{10}{|l|}{ Woodland and hedges } \\
\hline \multirow[t]{7}{*}{ Abies alba Mill. } & fir & whole needle & $\mathrm{w}$ & 1 & 6 & 1 & - & 2 & 10 \\
\hline & & needle tip & c & - & - & - & 1 & - & 1 \\
\hline & & needle base & $\mathrm{w}$ & - & 233 & - & 1 & 117 & 351 \\
\hline & & needle base & c & 1 & - & - & - & - & 1 \\
\hline & & needle fragment & $\mathrm{w}$ & - & 742 & - & 5 & 476 & 1223 \\
\hline & & needle fragment & c & - & 2 & 1 & - & 1 & 4 \\
\hline & & twig fragment & $\mathrm{w}$ & - & 1 & - & - & - & 1 \\
\hline Betula & birch & nut & $\mathrm{w}$ & - & 1 & - & - & - & 1 \\
\hline cf. Fagus sylvatica L. & beech & cupula & $\mathrm{w}$ & - & - & - & 1 & - & 1 \\
\hline \multirow[t]{6}{*}{ Picea abies (L.) H. Karsten } & spruce & whole needle & $\mathrm{w}$ & 5 & 3 & - & 1 & - & 9 \\
\hline & & needle tip & c & - & 1 & 1 & 2 & - & 4 \\
\hline & & needle base & $\mathrm{w}$ & 35 & 62 & 3 & 4 & 57 & 161 \\
\hline & & needle fragment & $\mathrm{w}$ & 164 & 67 & 10 & 6 & 51 & 298 \\
\hline & & needle fragment & c & - & 1 & 3 & 2 & 1 & 7 \\
\hline & & twig fragment & $\mathrm{w}$ & 1 & 6 & - & - & - & 7 \\
\hline Rubus fruticosus L. agg. & blackberry & drupe & $\mathrm{w}$ & - & 8 & - & - & - & 8 \\
\hline Rubus idaeus $\mathrm{L}$. & raspberry & drupe & $\mathrm{w}$ & - & 24 & - & - & 2 & 26 \\
\hline Rubus fruticosus L. agg./ R. idaeus $\mathrm{L}$. & blackberry/raspberry & drupe & $\mathrm{w}$ & - & 17 & - & - & - & 17 \\
\hline Sambucus nigra $\mathrm{L}$. & elder & seed & $\mathrm{w}$ & 141 & 148 & - & - & 14 & 303 \\
\hline Sambucus ebulus L./ S. nigra L. & dwarf elder/elder & seed & $\mathrm{w}$ & - & 1 & - & - & 3 & 4 \\
\hline Sorbus aucuparia $\mathrm{L}$. & rowan & drupe & $\mathrm{w}$ & - & - & - & - & 1 & 1 \\
\hline \multicolumn{10}{|l|}{ Disturbed, rough and open ground } \\
\hline Cirsium arvense (L.) Scop. & creeping thistle & achene & $\mathrm{w}$ & - & 2 & - & - & - & 2 \\
\hline Linum catharticum $\mathrm{L}$. & fairy flax & seed & $\mathrm{w}$ & - & 1 & - & - & - & 1 \\
\hline Silene vulgaris Garcke & bladder campion & seed & $\mathrm{w}$ & 1 & - & - & - & - & 1 \\
\hline
\end{tabular}


Table 2. Continued

\begin{tabular}{|c|c|c|c|c|c|c|c|c|c|}
\hline \multicolumn{4}{|l|}{ MAUKEN A: Mining area } & \multicolumn{2}{|c|}{ Cut 6} & \multirow{2}{*}{$\frac{\text { Cut } 7}{\text { Smelting location }}$} & \multicolumn{3}{|c|}{ Cut 10} \\
\hline \multicolumn{4}{|c|}{ MACROBOTANICAL ANALYSES } & \multicolumn{2}{|c|}{ Slag processing site } & & \multicolumn{3}{|c|}{ Slag heap } \\
\hline Stellaria media (L.) Vill. & chickweed & seed & $\mathrm{w}$ & 1 & 4 & - & - & 3 & 8 \\
\hline Taraxacum & dandelion & achene & $\mathrm{w}$ & - & - & - & - & 1 & 1 \\
\hline Urtica dioica $\mathrm{L}$. & common nettle & nut & $\mathrm{w}$ & 10 & 18 & - & - & 6 & 34 \\
\hline \multicolumn{10}{|l|}{ Other wild plant taxa } \\
\hline Apiaceae & carrot family & mericarp & $\mathrm{w}$ & - & 1 & - & - & - & 1 \\
\hline Bromus & brome & caryopsis & c & - & 1 & - & - & - & 1 \\
\hline Persicaria/Polygonum & knotweed/knotgrass & nut & $\mathrm{w}$ & - & - & - & - & 1 & 1 \\
\hline Silene & campion & seed & $\mathrm{w}$ & - & 1 & - & - & - & 1 \\
\hline Torilis & hedge-parsley & mericarp & $\mathrm{w}$ & - & 1 & - & - & - & 1 \\
\hline Sum of macrobotanical remains & & & & 431 & 1804 & 23 & 27 & 961 & 3246 \\
\hline \multicolumn{10}{|l|}{ Other components } \\
\hline charcoal & & & c & $\mathrm{x}$ & $\mathrm{x}$ & $\mathrm{xx}$ & $\mathrm{xx}$ & $\mathrm{xx}$ & \\
\hline roots/rootlets & & & $\mathrm{w}$ & $\mathrm{xx}$ & - & - & $\mathrm{xx}$ & - & \\
\hline bark fragments & & & $\mathrm{w}$ & - & $\mathrm{x}$ & $\mathrm{x}$ & - & $\mathrm{x}$ & \\
\hline buds & & & $\mathrm{w}$ & - & $\mathrm{x}$ & - & - & $\mathrm{x}$ & \\
\hline unidentifiable plant fibres & & & $\mathrm{w}$ & $\mathrm{xx}$ & - & - & - & - & \\
\hline wood fragments & & & $\mathrm{w}$ & $\mathrm{x}$ & $\mathrm{xxx}$ & $\mathrm{xx}$ & $\mathrm{xx}$ & $\mathrm{xx}$ & \\
\hline Bryophyta (stem and leaves) & & & $\mathrm{w}$ & $\mathrm{x}$ & $\mathrm{xx}$ & $\mathrm{x}$ & $\mathrm{x}$ & $\mathrm{xx}$ & \\
\hline leaf fragments & & & $\mathrm{w}$ & - & - & - & - & $\mathrm{xx}$ & \\
\hline Cenococcum geophilum (sclerotia) & & & $\mathrm{w}$ & $\mathrm{x}$ & $\mathrm{x}$ & $\mathrm{x}$ & $\mathrm{x}$ & $\mathrm{xx}$ & \\
\hline \multicolumn{10}{|l|}{ Bone fragments } \\
\hline unidentified bone fragments & & & & - & - & $\mathrm{x}$ & $\mathrm{x}$ & - & \\
\hline mammalia bone fragments & & & & $\mathrm{xx}$ & - & - & - & - & \\
\hline \multicolumn{10}{|l|}{ Insect remains } \\
\hline beetle remains (e.g. elytron) & & & & - & $\mathrm{x}$ & - & $\mathrm{x}$ & $\mathrm{x}$ & \\
\hline earthworm egg capsules & & & & $\mathrm{x}$ & $\mathrm{x}$ & - & $\mathrm{x}$ & - & \\
\hline fly puparia & & & & $\mathrm{x}$ & - & - & - & - & \\
\hline beetle larvae & & & & - & - & - & $\mathrm{x}$ & - & \\
\hline unidentified insect remains & & & & - & - & - & - & $\mathrm{x}$ & \\
\hline \multicolumn{10}{|l|}{ Inorganics } \\
\hline slag & & & & $\mathrm{xx}$ & $\mathrm{xx}$ & - & $\mathrm{x}$ & $\mathrm{xx}$ & \\
\hline stones & & & & - & - & - & - & $\mathrm{xx}$ & \\
\hline sediment lumps & & & & $\mathrm{x}$ & - & - & - & - & \\
\hline
\end{tabular}


moderate number of decayed waterlogged seeds, fruits and pine needles. The most abundant plant taxa recorded include wood species such as spruce and fir. Additionally, hedgerow taxa and shrubs from clearings (e.g. blackberry, Rubus fruticosus and raspberry, $R$. idaeus; elder, Sambucus nigra) were also found. Frequent finds of wild plant species, such as chickweed (Stellaria media) and common nettle (Urtica dioica), indicate areas of rough and open ground. Charcoal fragments are also present in all samples, with spectra (Table 3) being dominated by the climax-wood taxa spruce (PicealLarix type), beech and fir, whereas larch (Larix/ Picea type), hazel, alder (Alnus) and black elder are present in smaller quantities.

Analyses of charcoal from all three locations at the Mauk A site show evidence for anthropogenic impact (Table 3). Previous charcoal studies of Heiss and Oeggl (2008) at the Mauk A ore processing site, the surroundings of the Mauk D mine shaft and on a fire-set pit of the Mauk B mine also recorded taxa of a mixed forest with occasionally admixed pioneer species. The charcoal analyses therefore indicate the use of timber as fuel from a semi-natural mixed forest (Abieti-Fagetum) which fulfils the combustion requirements for high temperature and long-burn processes such as smelting. The minor quantities of taxa from rough/open ground suggest small-scale open areas near the mining site due to human impact on local forests.

There is no evidence for cultivated plant remains from these samples, indicating that no crop processing activities were carried out at the Mauk A site. However, Heiss and Oeggl (2005) found a single instance of broomcorn millet (Panicum miliaceum), which simply represents waste from human activities nearby.

Animal bones are documented both at the Mauk A smelting site and the Mauk D mine shafts within in a few hundred metres of one another (Figure 8). The majority of bones, a total of 4005 fragments weighing about $20 \mathrm{~kg}$, were hand-collected. Whereas the bones from Mauk D are restricted to a single complex in the mining waste tip (Halde MD; $\mathrm{n}=$ 1426; 2000 excavation), the 2579 bone fragments from Mauk A stem from two furnaces (Ofen MA), two waste tips (Halde 07 MA, Halde 08 MA) and hearths (FS MA). Specimen numbers vary between 156 and 736 fragments (Schibler et al. 2009: 94). A further 820 bone fragments were obtained by wet sieving of sediment samples.

At Mauk A samples were collected from a $1.5 \times 2 \mathrm{~m}$ test area in a slag-sand tip excavated in $100 \mathrm{~mm}$ arbitrary layers and passed through $0.35 \mathrm{~mm}$ minimum mesh sieves. Our aim was to find out whether small animals, like fish or small birds, contributed to the miners' diet. At the same time, we could control whether the assemblage of skeletal elements from the hand-collected bones were unrepresentative through a lack of smaller fragments. Due to copper salts contained in the sediments, the bones have taken on a turquoise to green colour. The humid conditions prevailing in the slag-sand deposits and the toxic, antibacterial effects of the copper salts provided highly favourable conditions for the preservation of the animal bones. Most bone surfaces were smooth, flaking is rare. Sharp edges showed that fractures were produced in the slaughtering and portioning of carcasses (Hüster Plogmann et al. 2011). The lack of edge-rounding indicates that there was virtually no redeposition.

The proportions of identifiable bones among the hand-collected specimens vary between $51 \%$ (Halde $08 \mathrm{MA}$ ) and 75\% (Halde MD), with an overall average of $65 \%$. Based on bone weight, at least $90 \%$ are identifiable, 94\% overall (Schibler et al. 2009: 95-6, figs. 3 \& 4). There are only two wild animal bones (Ofen MA) among the 2599 identified specimens in 
Table 3. Taxa composition of charcoal analyses from five soil samples at Mauk A.

\begin{tabular}{|c|c|c|c|c|c|c|c|c|}
\hline \multirow{2}{*}{\multicolumn{2}{|c|}{$\frac{\text { MAUKEN A: Mining area }}{\text { CHARCOAL ANALYSES }}$}} & \multirow{2}{*}{\multicolumn{2}{|c|}{$\frac{\text { Cut } 6}{\text { Slag processing site }}$}} & \multirow{3}{*}{$\begin{array}{c}\frac{\text { Cut } 7}{\text { Smelting location }} \\
103\end{array}$} & \multicolumn{3}{|c|}{ Cut 10} & \\
\hline & & & & & Slag heap & & & \\
\hline Sample number & & 13 & 17 & & B6 & $\mathrm{D} 4$ & & \\
\hline Total sample volume (l) & & 5 & 5 & 2 & 2 & 2 & & \\
\hline Total sample weight $(\mathrm{kg})$ & & 5.99 & 4.87 & 1.12 & 1.96 & 2.46 & & \\
\hline $\begin{array}{l}\text { Total charcoal weight } \\
>2 \mathrm{~mm}(\mathrm{~g})\end{array}$ & & 4.61 & 2.61 & 4.58 & 13.16 & 5.13 & & \\
\hline $\begin{array}{l}\text { Analysed charcoal weight } \\
>2 \mathrm{~mm}(\mathrm{~g})\end{array}$ & & 1.55 & 1.18 & 1.64 & 3.68 & 2.70 & & \\
\hline Mean fragment weight (mg) & & $\begin{array}{c}31 \\
\mathrm{n}\end{array}$ & $\begin{array}{c}24 \\
\mathrm{n}\end{array}$ & $\begin{array}{c}33 \\
\mathrm{n}\end{array}$ & $\begin{array}{c}74 \\
\mathrm{n}\end{array}$ & $\begin{array}{c}54 \\
\mathrm{n}\end{array}$ & $\sum$ & $\%$ \\
\hline Abies alba Mill. & fir & 6 & 3 & 10 & 5 & 2 & 26 & 10.4 \\
\hline Piceal Larix type & spruce/larch & 29 & 34 & 32 & 27 & 18 & 140 & 56.0 \\
\hline Larix/Picea type & larch/spruce & - & - & 1 & - & 6 & 7 & 2.8 \\
\hline Coniferous wood (indet.) & - & - & - & 1 & - & 3 & 4 & 1.6 \\
\hline Fagus sylvatica $\mathrm{L}$. & beech & 12 & 13 & 6 & 15 & 11 & 57 & 22.8 \\
\hline Acer sp. & maple & - & - & - & - & 1 & 1 & 0.4 \\
\hline cf. Acer & maple & - & - & - & - & 2 & 2 & 0.8 \\
\hline Alnus sp. & alder & - & - & - & - & 3 & 3 & 1.2 \\
\hline Corylus avellana $\mathrm{L}$. & hazel & 1 & - & - & 1 & - & 2 & 0.8 \\
\hline Sambucus nigra L. & black elder & 1 & - & - & - & - & 1 & 0.4 \\
\hline Broad leaved wood (indet.) & - & 1 & - & - & 2 & 4 & 7 & 2.8 \\
\hline $\begin{array}{l}\text { Analysed charcoal } \\
\text { fragments (total) }\end{array}$ & & 50 & 50 & 50 & 50 & 50 & 250 & 100 \\
\hline
\end{tabular}

$\sum$ Sum of analysed charcoal fragments

$\%$ Percentage of analysed charcoal fragments

$n$ Number of analysed charcoal fragments 


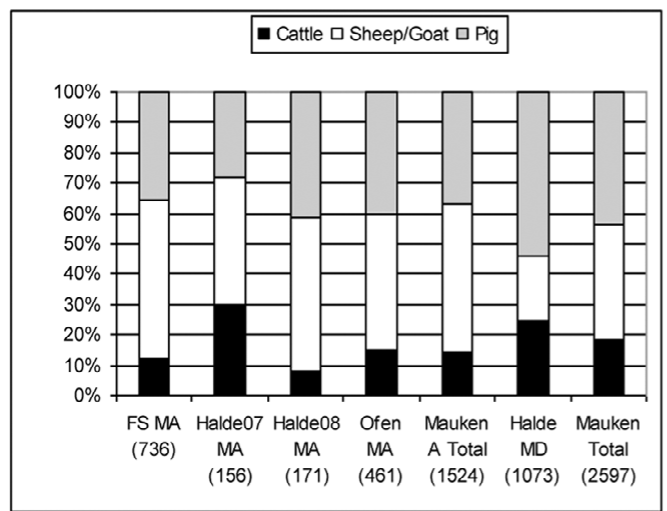

A

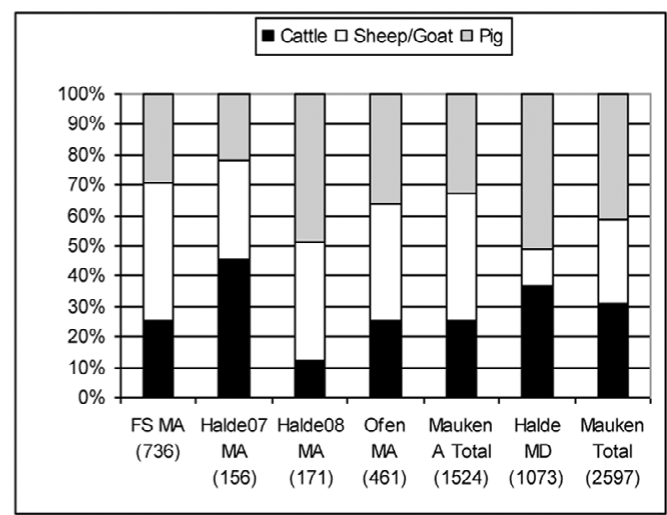

B

Figure 8. Importance of animal species at different sites of Mauk $A$ and D: A) on the basis of fragment numbers; $B)$ on the basis of bone weight.

the hand-collected material, the humerus of a pine marten and the mandible of a common vole. The wet sieving residues from Mauk A, which yielded only very small fragments of large and medium sized mammals, also contained only one thoracic vertebra of a small wild mammal. Hunting apparently played no significant role in the diet of the miners from the Mauken area.

The domestic species represented were cattle, pig and sheep/goat. For the latter, the majority of identified fragments were of sheep $(n=140)$ whereas goat was documented only once. Based on both fragment numbers and bone weight, domestic pigs and ovicaprids are more frequent than cattle in most of the complexes. Only in two features (Halde 07 MA and Halde MD) are cattle a little more numerous. All in all, the bones of domestic animals comprise 44\% pig, 38\% ovicaprids and cattle barely 19\%. Bone weight, which denotes the importance of a species in relation to meat quantity, indicates that pork (41\%) is more important than ovicaprid meat $(28 \%)$ and beef $(31 \%)$. Even though there were no dog bones, gnaw-marks attest to their presence among the miners.

A comparison with other Swiss and Austrian Bronze Age sites from the Alpine area reveals that cattle proportions are uncommonly low in Mauken (Figure 9), with most other sites showing percentages above $40 \%$. Cattle seems to have been especially important in the western Alpine region (Lichtenstein, Graubünden) and have become even more so during the Bronze Age. Only the Kitzbühel-Kelchalpe site, where the green coloration of the bones also indicates copper mining (Amschler 1937) has comparably low cattle percentages. Copper salts are toxic in high concentrations. Contaminated green fodder can result in poisoning of ruminants, so that stock breeding near the excavated activity centres is unlikely. Due to the unfavourable geographical conditions, large-scale cattle herding is doubtful in the vicinity of the Mauk A and D sites.

Only few remains of very young or older breeding animals are present in the investigated sites (Hüster Plogmann et al. 2011), indicating that the ruminants were most probably not kept for secondary products such as milk, wool or as working or breeding animals; the indications are that their main purpose was the provision of meat. In rural settlements, 


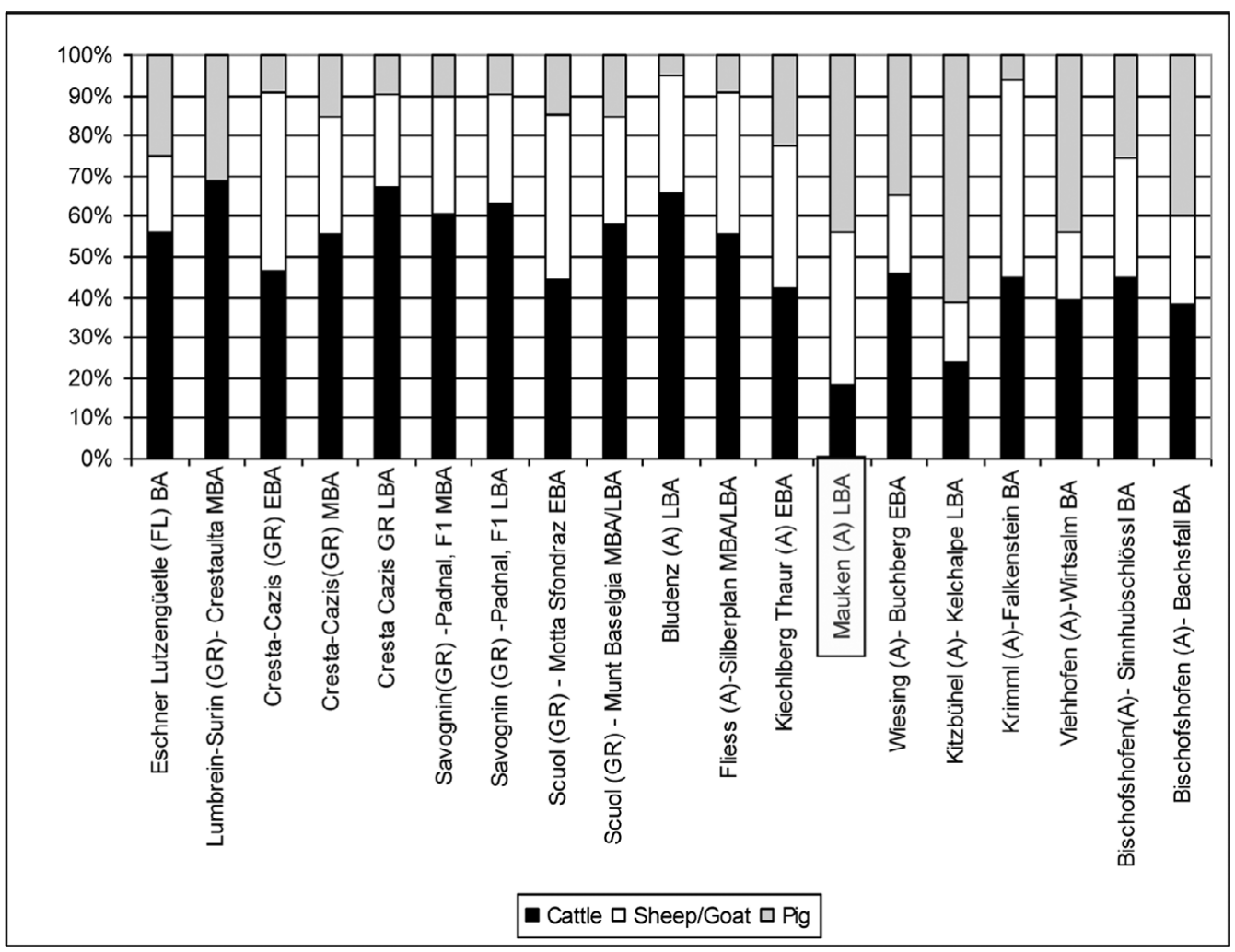

Figure 9. Importance of different domestic animal species in selected Bronze Age sites in the Alpine region of Austria and Switzerland.

animal breeding and the use of secondary products normally play a bigger role which is reflected in higher percentages of older animals: in Cresta Cazis (GR) these amount to 26$34 \%$ of the adult sheep/goats during different settlement phases and 30-50\% of the cattle (Plüss 2007). In Mauken, by contrast, the emphasis of skeletal parts indicates a selection of body parts rich in meat and fat (Schibler et al. 2009: 102, fig. 9). Elements of the torso (vertebrae and ribs) are under-represented in all domestic species. In sheep (and goats), the upper and intermediate regions of the extremities prevail, whereas in pigs skull elements and the upper parts of the meat-rich extremities are most frequent. In cattle, skull elements and the upper or intermediate parts of the extremities are again numerous. Characteristic scorch marks on a cattle mandible are known from ethnological parallels to be the result of slow stewing, indicating that heads were eaten and are not just waste.

These results imply that the Mauken miners were supplied with the meat of prime yield animals from farms in the wider neighbourhood. It is possible that animals were brought in live for slaughter, and kept near the site for short periods. But in addition, there seems to have been a supply of meat-rich joints - possibly even deboned or preserved cuts. At present, we do not have sufficient data to decide whether supply was the result of trade or the provision of victuals in exchange for services. 

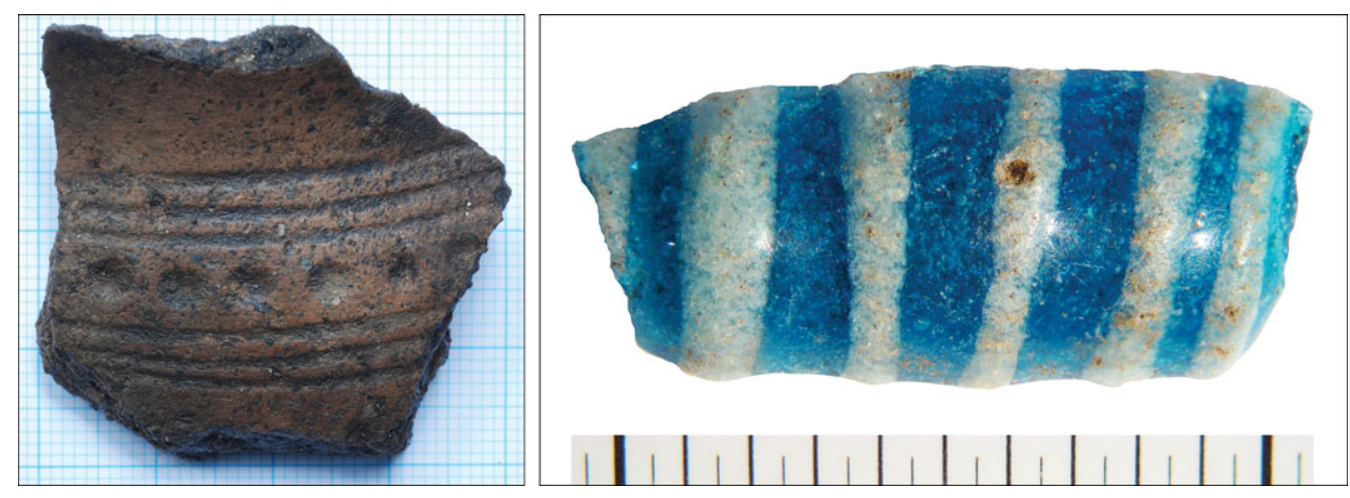

Figure 10. Ceramic fragment of fine ware with indentation ornament (left) and a barrel-shaped blue glass bead with white thread inlay (right) from the Mauk A smelting site (2008 excavations).

\section{Dating}

Ceramics from the Mauk A smelting site (2008 excavations) are for the most part typologically inconclusive, although Reider (2003) assigned pottery fragments discovered during excavations at Mauk A in the 1990s mostly to the Ha A1 and A2 phases. There is, however, a fragment of decorated fine ware with indentation (Figure 10). This typological trait also appears in funerary vessels (beakers, cups) in Urnfield culture graves in the North Tyrol Inn Valley, which date to the SB IIb (Ha A2: 1155-1085 BC) and SB IIc (Ha B1: 1085-1020 BC) phases (Sperber 1978, 2004). A barrel-shaped blue glass bead with white thread inlay (Figure 10) corresponds to North Tyrol Urnfield culture graves of the SB IIa (Ha A1: 1205-1155 BC) and SB IIb phases (Sperber 1978, 2004). In all, the typologically significant artefacts from the Mauk A smelting site indicate an occupation in the twelfth/eleventh centuries BC.

With the exception of one wooden board, charcoal was used for radiocarbon dating of the Mauk A site. The calibrated dates cover a wide span of 400 to 500 years (Figure 11). The younger six radiocarbon results cluster relatively closely, and the older results can probably be attributed to the 'old wood' effect. The distribution and averaging of the six younger, relatively congruent data (mean: $2891 \pm 15 \mathrm{BP}, 2 \sigma: 1130-1010 \mathrm{cal} \mathrm{BC}$ ) suggest that the main activity phase at the Mauk A smelting site occurred in the late twelfth and the eleventh centuries BC.

A multi-phase use is established for the Mauk D mine shafts where activities date to the late twelfth to early tenth centuries as well as to the ninth century BC. This last phase of Mauk D probably coincides with activities in Schwarzenberg-Moos (Mauk F), where the waterlogged preservation of the wood permits the dendrochronological dating of the site to a period from about 900 to 869 BC (Nicolussi et al. 2009). The latest prehistoric mining activities are recorded at Mauk E in the late eighth century BC based on the dendrochronological analysis of carbonised wood from fire-setting (Pichler et al. 2010). Solitary radiocarbon dates indicate that the Mauk B and C sites were active in the same late period. 


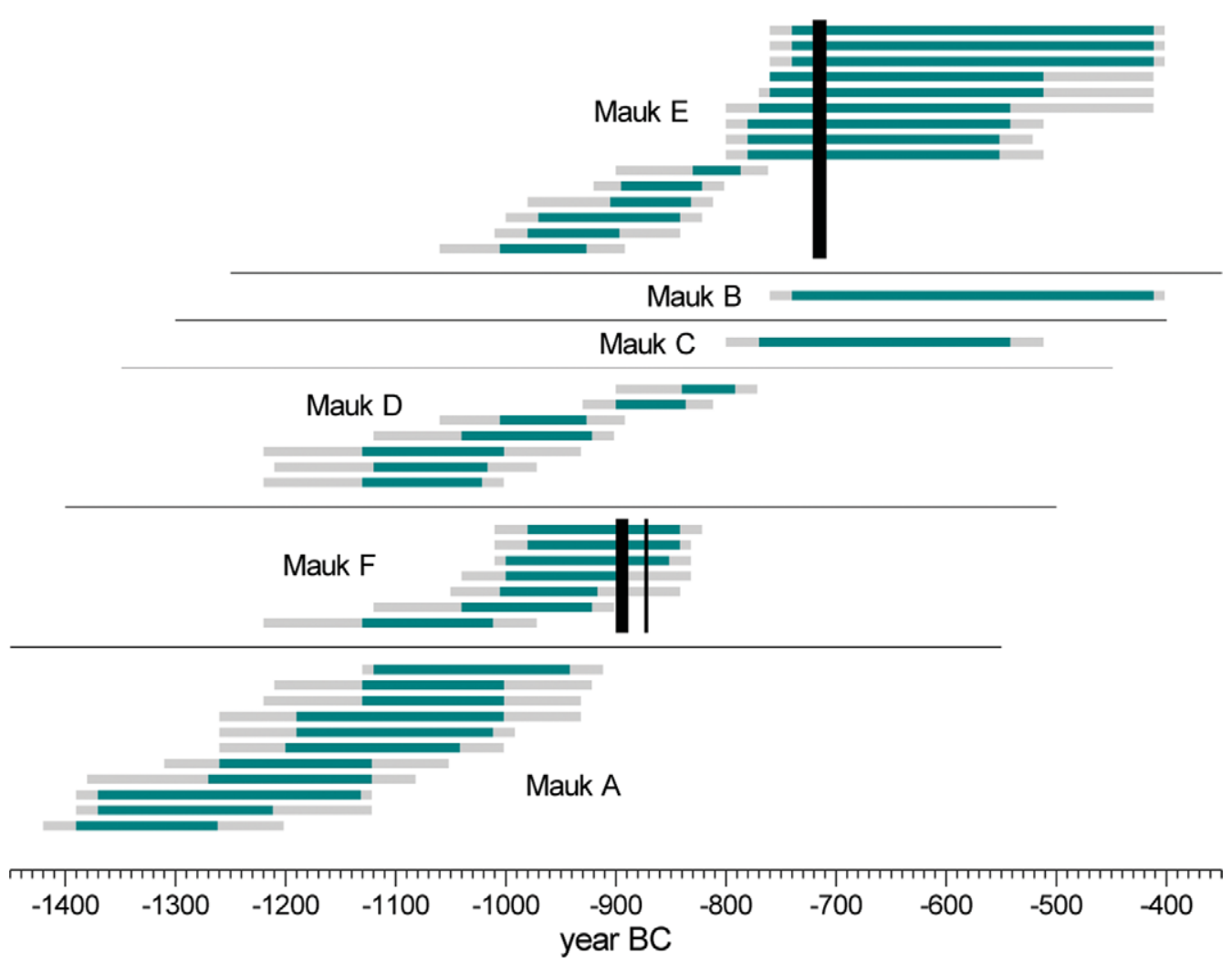

Figure 11. Calibrated radiocarbon dates of the sites Mauk $A$ to $F$ and dendrochronological dates from Mauk $E$ and $F$.

\section{Discussion: the miners' life}

The Mauken miners operated in a forest environment, and were largely supplied from the valley below. Pollen analyses document agro-pastoral settlements on the valley floor and a thinning of forests at higher altitudes by mining and/or pastoral activities. There are no cultivated plants, and specifically no cereals, among the botanical macroremains or the local pollen record. Even considering the poor state of preservation of the botanical material, one would expect to find some remains of cultivated plants if these were grown and processed near the sites. Their absence therefore indicates that cultivated plants were not grown in the vicinity of the mining sites. Additionally, wild plants like elder, raspberry or blackberry were very rarely collected and consumed.

When compared to other Alpine Bronze Age sites, the archaeozoological samples of the Mauk A and D sites exhibit a special composition. Distinctly more pork was consumed than beef, which was eaten about as much as mutton and goat meat. Analyses of the slaughter ages and the frequency of skeletal parts show that prime age animals are most frequent and represented chiefly by body parts rich in meat and fat. The results indicate that choice, even 
partially preserved cuts of meat were delivered to the Mauken mining area. It seems possible, however, that smaller herds of ruminants were kept in the neighbourhood of the sites to serve as walking larders and/or milkers. This is corroborated by pollen analyses, which signal an increase in pasture in the Schwarzenberg-Moos area in the Late Bronze Age.

The food supply seems to be characterised by the import of both plant and animal foodstuffs. Processed plant foodstuffs such as bread or cleaned cereal could be consumed at once or easily prepared as stews. Choice cuts of meat, preserved (ham, bacon) ready to eat or uncured for cooking, supplemented the menu and made stews richer and more savoury. These foods were apparently complemented by milk (from cows, goats and sheep) and dairy products (yoghurt, fresh or ripe cheese). For this purpose, dairy animals were evidently kept in the close vicinity of the Mauk A and F sites, as suggested by pollen analyses. Dairying was probably limited to the summer season as providing fodder for animals during winter would have been very demanding. The Mauken miners were therefore not totally dependent on food imports but managed to produce some foodstuffs like milk and dairy products for themselves on a small, seasonal scale. As a consequence, the Mauken mining area can be viewed as a system in between consumer and producer sites, although in the matter of food, external supply vastly outweighed local production.

\section{Acknowledgements}

The HiMAT 'History of Mining Activities in the Tyrol and adjacent Areas' special research program at Innsbruck University, supported by the Austrian Science Fund (FWF project number: F31-GO2), has been investigating key issues concerning prehistoric and historic mining in the Eastern Alps, especially in Tyrol and Salzburg, since 2007.

\section{References}

AMSCHLER, W. 1937. Die Haustierreste von der Kelchalpe bei Kitzbühel. Mitteilungen der Prähistorischen Kommission der Akademie der Wissenschaften 3: 96-120.

Bartels, C., A. Bingener \& R. Slotta. 2006. Das Schwazer Bergbuch. Faksimile in 3 Bänden. Bochum: Deutsches Bergbau-Museum.

BERGGREN, G. 1981. Atlas of seeds and small fruits of Northwest-European plant species with morphological descriptions 3. Stockholm: Swedish Museum of Natural History.

CAPpers, R.T.J., R.M. BEKKER \& J.E.A. JANS. 2006. Digitale Zadenatlas van Nederland. Gronigen: Barkhuis Publishing.

GoldenBERG, G. 2008. Urgeschichtlicher Kupferbergbau bei Radfeld. Dorfbuch Radfeld: 65-70.

Goldenberg, G. \& B. Rieser. 2004. Die Fahlerzlagerstätten von Schwaz/Brixlegg (Nordtirol). Ein weiteres Zentrum urgeschichtlicher Kupferproduktion in den österreichischen Alpen, in G. Weisgerber \& G. Goldenberg (ed.) Alpenkupfer - Rame delle Alpi (Der Anschnitt Beiheft 17): 37-52. Bochum: Deutsches Bergbau-Museum.
HeIss, A.G. \& K. OEgGL. 2005. The oldest evidence of Nigella damascena L. (Ranunculaceae) and its possible introduction to Central Europe. Vegetation History and Archaeobotany 14: 562-70.

-2008 . Analysis of the fuel wood used in Late Bronze Age and Early Iron Age copper mining sites of the Schwaz and Brixlegg area (Tyrol, Austria). Vegetation History and Archaeobotany 17: 211-21.

Hưster Plogmann, H., S. Deschler-Erb, N. PÖllath, J. Schibler \& B. STOPp. 2011. Schweinskopf und Schafschlegel für die Bergleute? Archäologie Österreich Spezial 4 (in press).

JaCOMET, S. \& A. Kreuz. 1999. Archäobotanik. Stuttgart: Ulmer.

Klaunzer, M., G. Goldenberg, S. Hye, M. Staudt, U. TöChterle \& G. TOMEdi. 2010. Prehistoric Fahlore mining and smelting in the Mauken Valley, North-Tyrol, in P. Anreiter, G. Goldenberg, K. Hanke, R. Krause, W. Leitner, F. Mathis, K. Nicolussi, K. Oeggl, E. Pernicka, M. Prast, J. Schibler, I. Schneider, H. Stadler, T. Stöllner, G. Tomedi \& P. Tropper (ed.) Mining in European history and its impact on environment and human societies. Proceedings for the $1^{\text {st }}$ Mining in European History Conference of the SFB-HiMAT, 12.-15. November 2009: 345-9. Innsbruck: Innsbruck University Press. 
MAYER, H. 1964. Bergsturzbesiedlungen in den Alpen. Mitteilungen aus der Staatsforstverwaltung Bayerns 34: 191-2003.

Nicolussi, K., A. Thurner \& T. Pichler. 2009. Dendrochronologische Untersuchungen zur prähistorischen Erzaufbereitungsanlage Schwarzenberg-Moos bei Brixlegg, in K. Oeggl \& M. Prast (ed.) Die Geschichte des Bergbaus in Tirol und seinen angrenzenden Gebieten. Proceedings zum 3. Milestone-Meeting des SFB-HiMAT vom 23.-26. Oktober 2008 in Silbertal, Innsbruck: 317-23. Innsbruck: Universität Innsbruck.

Pichler, T., K. Nicolussi, A. Thurner \& G. GOLDENBERG. 2010. Dendrochronological dating of charcoal originating from an Early Iron Age fire-set pit in the mining area of Schwaz/Brixlegg (Tyrol, Austria), in P. Anreiter, G. Goldenberg, K. Hanke, R. Krause, W. Leitner, F. Mathis, K. Nicolussi, K. Oeggl, E. Pernicka, M. Prast, J. Schibler, I. Schneider, H. Stadler, T. Stöllner, G. Tomedi \& P. Tropper (ed.) Mining in European history and its impact on environment and human societies. Proceedings for the $1^{\text {st }}$ Mining in European History Conference of the SFB-HiMAT, 12.-15. November 2009: 233-7. Innsbruck: Innsbruck University Press.

PIRKL, H. 1961. Geologie des Trias-Streifens und des Schwazer Dolomits südlich des Inn zwischen Schwaz und Wörgl (Tirol). Jahrbuch der Geologischen Bundesanstalt 104: 1-150.

PLƯss, P. 2007. Archäozoologische Untersuchungen der Tierknochen aus Cresta-Cazis (GR) und ihre Bedeutung für die Umwelt-, Ernährungs-und Wirtschaftsgeschichte während der alpinen Bronzezeit. Unpublished PhD dissertation, University of Basel.

REIDER, E. 2003. Die spätbronzezeitlichen Kleinfunde aus den bergbauarchäologischen Untersuchungen im Raum Radfeld. Unpublished Diploma dissertation, University of Innsbruck.

Rieser, B. \& H. Schrattenthaler. 2000. Urgeschichtlicher Kupferbergbau im Raum Schwaz-Brixlegg, Tirol. Archaeologia Austriaca 82/83: 135-79.
Schatz, I., H. Schatz, F. Glaser \& A. Heiss. 2002. Subfossile Arthropodenfunde in einer bronzezeitlichen Grabungsstätte bei Radfeld (Tirol, Osterreich) (Acari: Oribatida; Insecta: Coleoptera, Hymenoptera: Formicidae). Berichte des naturwissenschaftlich-medizinischen Vereins Innsbruck 89: 249-64.

Schibler J., S. Deschler-Erb, H. Húster Plogmann, N. PÖllath \& B. STOPP. 2009. Fleischversorgung in Fundstellen des bronzezeitlichen Bergbaus. Beispiele aus dem HiMAT-Projekt, in K. Oeggl \& M. Prast (ed.) Die Geschichte des Bergbaus in Tirol und seinen angrenzenden Gebieten. Proceedings zum 3. Milestone-Meeting des SFB-HiMAT vom 23.-26. Oktober 2008 in Silbertal, Innsbruck: 91-107. Innsbruck: Universität Innsbruck.

SCHOCH, W.H., I. Heller, F.H. SchweIngruber \& F. KIENAST. 2004. Wood anatomy of Central European species. Available at: www.wsl.ch/land/products/ dendro/key.pdf (accessed 4 May 2011).

SCHWEINGRUBER, F.H. 1990. Anatomie europäischer Hölzer. Bern: Haupt.

SPERBER, L. 1978. Nordtiroler Urnenfelderkultur. Unpublished typescript, University of Innsbruck.

- 2004. Zur Bedeutung des nördlichen Alpenraumes für die spätbronzezeitliche Kupferversorgung in Mitteleuropa - mit besonderer Berücksichtigung Nordtirols, in G. Weisgerber \& G. Goldenberg (ed.) Alpenkupfer - Rame delle Alpi (Der Anschnitt Beiheft 17): 303-345. Bochum: Deutsches Bergbau-Museum.

Tinner, W. \& A.F. LotTer. 2006. Holocene expansions of Fagus silvatica and Abies alba in Central Europe: where are we after eight decades of debate? Quaternary Science Reviews 25: 526-49.

WALDE, C. 1999. Palynologische Untersuchungen zur Vegetations- und Siedlungsgeschichte im Raum Kramsach-Brixlegg (Tirol, Österreich). Berichte des naturwissenschaftlich-medizinischen Vereins Innsbruck 86: 61-79. 